\title{
An empirical study on relationship between organizational culture and administrative corruption
}

\author{
Saeed Sehhat ${ }^{\mathrm{a}}$, Mehdi Jafarzadeh kenari ${ }^{\mathrm{b}^{*}}$ and Mohsen Mijani ${ }^{\mathrm{c}}$
}

\begin{abstract}
${ }^{a}$ Assistant Professor of Management, Allameh Tabatabae'i University, Tehran, Iran
${ }^{b}$ Master of Business Administration, Allameh Tabatabae'i University, Tehran, Iran

${ }^{c}$ Master of Business Administration, Allameh Tabatabae'i University Tehran, Iran

ART ICLEINFO ABSTRACT
\end{abstract}

Article history:

Received January 8, 2012

Received in Revised form

April, 25, 2012

Accepted 1 May 2012

Available online

May 42012

Keywords:

Bureaucratic culture

Organic culture

Bureaucratic health

Bureaucratic corruption

\begin{abstract}
Bureaucratic corruption is an organizational phenomenon, which faces the trend of countries' development with serious problems. In spite of all planning and respects of countries to fight against this phenomenon, we are still observing its growth in various aspects of the community. The basic approach emphasized by present study is that it is necessary to establish a corruption prevention system whose central element is social culture and organizational culture rather than relying upon the trends based on punishment after corruption. To perceive the relationship between organizational culture and bureaucratic health of organizations, we used a field approach and selected four governmental organizations namely "governorship", "municipality", "traffic police" and "customs to gather the data. We used two questionnaires A and B to gather the data on organizational culture and the relationship between culture and corruption, respectively. Initially, by distributing questionnaire A, we evaluated all four organizations in a manner that two organizations have bureaucratic culture and two organizations with organic culture. Then, questionnaire B was distributed among employees and clients of studied organizations (to acquire realer information on bureaucratic health rate) to study the relationship between the type of organizational culture and bureaucratic health. Research statistical population consists of all employees and clients of bureaucratic organizations in Chabahar province located in south east of Iran. Statistical sample consists of 146 clients and 146 employees of all four studied organizations. The results from data analysis show that there is no significant relationship between organic or mechanic organizational culture and employees' bureaucratic health.
\end{abstract}

(C) 2012 Growing Science Ltd. All rights reserved.

\section{Introduction}

Bureaucratic corruption is the opposite point to bureaucratic health. It is considered as a great problem in public organizations of many countries and it is not simply a problem in developing countries though it is more dominated in such countries. According to most thinkers, corruption is an inevitable disease in all administrations and it does not belong to a continent, region, group or tribe (Ksenia, 2008). The beginning of corruptive actions is not in current age rather its background backs

* Corresponding author.

E-mail addresses: m.j.kenari@gmail.com (M. Jafarzad Kenari) 
to the history of the world. Hence, the age of corruption is the same as the age of government concept. Therefore, financial and bureaucratic corruption exist everywhere power and wealth are aggregated and a government exists (Zahedi, 2009). As general definition, corruption is deviation of an individual from right performance in its tasks and functions (in organization or community) through actions such as bribery, extortion and so on, which mitigate social honesty and increase distrust inside the society (Berthon et al., 2008).

According to World Bank, one trillion US dollars is paid annually as bribery in organization as a factor of bureaucratic corruption. The importance of such bribery becomes more evidence when we find that total income of global economy has been 30 trillion US dollars between 2001 and 2002 (Goel \& Nelson, 2010). Likewise, global bank has estimated that in developing countries, five percent of their exportation incomes are spurred into the pockets of corrupted staff (Sanyal \& Guvenli, 2009). According to World Bank experts, controlling bribery can increase national income remarkably and rapider growth of economy as well as better life quality such as mitigation of children death (World Bank, 2004). Principally, bureaucratic corruption is a fundamental problem in any society and, in a smaller scale, in any organization. Various organizational connoisseurs and practitioners have introduced different factors and grounds for emerging and expansion of bureaucratic corruption potentially or proactively. According to such factors, one can identify the ways that have more impact on mitigation or elimination of bureaucratic corruption in organizations. If we consider the organization as a system, we can see that it is formed by various subsystems of which one of the most important one is HR system. On this basis and in curbing bureaucratic corruption, concentration on factors that relate to human resources directly can have more impact on mitigation or elimination of bureaucratic corruption in organizations even though other organizational factors such as bureaucratic laws transparency are more effective in this field. Corruption backs to dominating culture of a nation or organization. One can claim that of 10 scholars in corruption field, 9 agree that corruption is an important national problem (Mungiu et al., 2011).

As a phenomenon shaped by policies and approaches on organizational senior managers, organizational culture is a factor made by human resources and plays a vital role in preventing corruption in organizations. Followed by new theories and researches in management, organizational culture is an important issue and it is considered as a major management discussion (Cheng et al., 2011).

The idea of studying organizations as culture (a system consisted of joint perceptions among members) is a relative new phenomenon. Until mid-1980s, organizations were logical tools in many regions, which could coordinate and control a group of people. In such condition, behavioral acceptable pattern will be axiomatic and it is the same thing that organizational culture pursues (Robins, 2005).

As a set of joint beliefs and values, organizational culture impacts on the behavior and thinking on organizational members and it can be considered as a starting point for motion and dynamism or as a barrier against progress. Organizational culture is the most fundamental ground of changes and transformations in organizations. Due to its strong impacting nature on the behavior and performance of members and organizations, organizational culture plays a crucial role in controlling employees' behaviors and is considered as an affecting factor on bureaucratic corruption. Organizational culture which has a close link to public culture is considered as an important factor in shaping organizational behavior and plays a vital role in creating changes in undesired behaviors and stability in organizational behaviors. Organizational culture has a very strong relationship with employees' organizational commitment and satisfaction. When organizational culture is closer to society's dominating culture, employees' satisfaction and commitment to organization would increase (Lau \& Ngo, 1996). In a set of joint beliefs and values which impacts on behavior and thinking of members and organization, organizational culture can be a source to achieve a bureaucratic healthy ambience or an environment, which assimilates bureaucratic corruption. 
Since bureaucratic corruption can significantly impact on development of the society and regarding the importance on organizational culture - as an important factor to prevent bureaucratic corruption we try to highlight the role of favorable organizational culture and establish a proper ground to increase managers' cognition to prevent an unfavorable phenomenon namely bureaucratic corruption.

\section{Research theoretical basics}

\subsection{Organizational culture}

Culture is a broad issue so sociologists, demographists, development economists, policymakers and cultural planners do not have a consensus on an absolute and complete definition and each one has provided a special definition. In a simple definition, culture is defined as national heritage. Organizational culture is traditions, ceremonies and ethics. Organizational culture includes values announced explicitly. Organizational culture covers joint learning in a joint history and it refers to structural strength and a paradigm for organizational evolution (Schine, 1997). Another definition is that culture is a complicated set of information, beliefs, arts, ethics, laws, traditions, ceremonies, capabilities and habits acquired by human. Culture is a factor, which constructs individual and social entity of the community and is a source of mechanisms and material and spiritual capitals of a nation in its evolutional and historical path. A group of researchers believe that culture is a set of knowledge, belief, art, ethics, laws, capabilities and habits by human as a member of the society (Kalahan et al., 1986). Organizations are the locations where people gather and work to achieve organizational aim(s) (Barney \& Griffin, 1999). In fact, organizations are social establishments to control the operation of achieving collective goals (Huczynski \& Buchanan, 1995). In other words, organizations are places to create informed management and necessary requirements to achieve goals through collective tools (Johnson \& Scholes, 1993). Like other organizational phenomena, organizational culture is defined in different ways. Denison (1997) believes that fundamental values, beliefs and assumptions in an organization, behavioral patterns resulted from joint values and symbols which show the links between assumptions, values and behaviors of organizational members are all called organizational culture. According to Nedaei (2008), organizational culture is a certain method or basis, which distinguishes an organization from other ones and, in fact, provides organization with a unique personality. It seems that there is consensus on the fact that organizational culture is a system of members' joint perceptions, which differs an organization from other ones. In a narrower review, this joint perception system is a set of key characteristics to which organization values (Robins, 1943).

\subsection{Types of organizational culture}

One can distinguish organizations in terms of organizational culture. On the other hand, since various factors impact on organizational culture, different cultures are seen in today organizations. The most preliminary categorization and description of organizational cultures belongs to Ketzdoris and Miler who provided five types of organizational culture:

1. Wise culture vs. self-sufficient culture

2. Obsessive culture vs. trusting culture

3. Avoiding culture vs. success-seeking culture

4. Political culture vs. focused on target culture

5. Bureaucratic culture vs. creative culture.

Another categorization of organizational culture which may one of the most comprehensive one is provided by Quinn and Gart. They divided organizational culture into four groups:

1. Rational culture

2. Ideological culture

3. Consensual culture

4. Hierarchical culture (Gudarzi \& Gominan, 2002). 
As a most general categorization, organizational culture is divided into two mechanistic and organic groups. Their characteristics are outlined in Table 1.

\section{Table 1}

The Characteristics of Mechanistic and Organic Cultures

\begin{tabular}{|c|c|c|}
\hline Organic culture & Compared characteristics & Bureaucratic or mechanistic culture \\
\hline $\begin{array}{l}\text { Flexible standards and tasks depended } \\
\text { to individual's decision }\end{array}$ & $\begin{array}{l}\begin{array}{l}\text { Standard rate } \\
\text { creativity by managers and } \\
\text { employees }\end{array}\end{array}$ & $\begin{array}{l}\text { Full determined } \\
\text { predetermined tasks }\end{array}$ \\
\hline $\begin{array}{l}\text { Creative and innovator } \\
\text { Welcoming new methods to work } \\
\text { Success - oriented }\end{array}$ & Risk - taking & $\begin{array}{l}\text { Traditional and conservative } \\
\text { Familiarity with current trends and } \\
\text { methods } \\
\text { Seeking for security }\end{array}$ \\
\hline $\begin{array}{l}\text { Non Emphasizing on the details of } \\
\text { employees' affairs }\end{array}$ & Respecting job details & $\begin{array}{l}\text { Emphasizing on the details of employees' } \\
\text { affairs }\end{array}$ \\
\hline Emphasizing on aim and outcome & Respecting the results of job & Emphasizing on the way of doing the job \\
\hline $\begin{array}{l}\text { Employee - oriented } \\
\text { Collective decision - making in } \\
\text { organization } \\
\text { Employees' contribution to managers } \\
\text { in decisions }\end{array}$ & $\begin{array}{l}\text { Respecting } \quad \text { organizational } \\
\text { members }\end{array}$ & $\begin{array}{l}\text { Task-oriented } \\
\text { Individual decision-making at the top of } \\
\text { organization } \\
\text { Employees do not participate in } \\
\text { organizational decision - making }\end{array}$ \\
\hline $\begin{array}{l}\text { Emphasizing on employees' interests } \\
\text { and organizational emphasis on } \\
\text { decisions }\end{array}$ & $\begin{array}{l}\text { The impact of outcomes and } \\
\text { decisions on employees }\end{array}$ & $\begin{array}{l}\text { Emphasizing on organizational interests in } \\
\text { decisions }\end{array}$ \\
\hline $\begin{array}{l}\text { Emphasizing on doing the jobs } \\
\text { collectively } \\
\text { Emphasizing on open communications } \\
\text { in organization }\end{array}$ & Respecting team working & $\begin{array}{l}\text { Impossibility of doing the jobs collectively } \\
\text { Emphasizing on closed communications in } \\
\text { organization }\end{array}$ \\
\hline $\begin{array}{llll}\text { The feeling of freedom and } \\
\text { independence in job }\end{array}$ & The & $\begin{array}{l}\text { Employees' dependency to superiors in } \\
\text { doing their jobs }\end{array}$ \\
\hline
\end{tabular}

\subsection{Bureaucratic health - corruption}

One of the most general definitions of corruption is to use public organizations for personal interests (Goel \& Nelson, 2010). In legal terms, bureaucratic corruption is to use bureaucratic/governmental authorities illegally for personal interests. According to this definition, it is assumed that there is a set of bureaucratic laws and regulations, which determine legal bureaucratic activities. Any behavior which is contrary to these rules and its motivation is personal benefit will be considered as bureaucratic corruption. Such definition of corruption is abstract when bureaucratic rules are complete, clear, fair and comprehensive and introduce precise laws for governmental and bureaucratic activities. Some authors define bureaucratic corruption on the basis of public opinion. They define corruption as initiatives that are considered unethical and harmful in terms of people's perspective. Such definition has a set of deficiencies including the differences between opinions by elites and the masses. According to such differences, political science researcher Hidden Himer divided bureaucratic corruption into three categories:

- Black bureaucratic corruption: an action which is hated by masses and political elites and its agent should be punished such as accepting bribery to neglect security standards and measures in home building

- Grey bureaucratic corruption: something hated by political elites while the masses are indifferent such as negligence of an employee to implement the laws that are not so popular among people and except than political elites, no one believes their usefulness.

- White bureaucratic corruption: actions that are apparently corruption and opposite to laws but most political elites and ordinary people do not consider them so harmful and significant to 
which they request punishment such neglecting some case of negating the laws that have lost their necessity due to social and cultural changes.

Some authors believe that bureaucratic corruption shows behaviors by some staff of an organization in their organizational roles and functions which are considered illegal, unethical and opposite to their social responsibility by the representatives of social control (Larmour, 2001; Palmer, 2008). In some other definitions, we face the problem where all classes of population may not have a similar conception on public interests. Contradictories between different social classes such as workers and capital owners may cause that a set of actions considered acceptable to public interests will be considered unacceptable by another group (Habiby, 1996).

According to Ashforth (2003), three processes cause normalization and repetition of bureaucratic corruption in organizations. They include institutionalization of corruption, rationalization of corruption and socialization of corruption. Whenever corruption is institutionalized, socialized and rationalized in a society, the ground for corruption growth and normalization will be paved. According to bureaucratic science practitioners, such behaviors as low working, discrimination among clients, accelerating the works of friends and acquaintances and similar behaviors are, inter alia, bureaucratic corruption. However, a further recognized type of corruption is "financial corruption" which its implications are embezzlement, bribery and abusing governmental assets and facilities (Tanzi, 1994). Scott (1972) believes that bureaucratic corruption refers to a behavior by which someone achieves more welfare due to his/her personal interests or a better status outside the official framework of tasks in a governmental position.

As a public organization with its headquarters in Germany, Transparency International Organization (TI) is established by Peter Eigen and its main aim is to fight against corruption. Each two years, it organizes a conference titled "International Conference on Fighting against Corruption" where various countries investigate the globe in terms of corruption and finally rank it. It depicts the rate of corruption in countries in zero-to-ten scale. Based on indicators, zero shows the highest and ten shows the lowest rate of corruption. In other words, higher score means lower corruption and higher health. Table 2 outlines the list of some countries (including Iran) with high or low corruption rate by TI in 2008. As seen, Denmark ranks the highest and Somali ranks the lowest in terms of corruption rate. In terms of health, Iran ranks 141 (2.3 score). It shows that the rate of corruption is in a relatively high level. Another important point is that most countries with lower corruption score (or higher corruption) are developing countries and most countries with higher corruption score (or lower corruption) are developed countries (TI, 2008).

Table 2

Rankings of Countries in Terms of Health (TI, 2008)

\begin{tabular}{lcccccccc}
\hline Country & $\begin{array}{c}\text { Corruption } \\
\text { score }\end{array}$ & Rank & Country & $\begin{array}{c}\text { Corruption } \\
\text { score }\end{array}$ & Rank & Country & $\begin{array}{c}\text { Corruption } \\
\text { score }\end{array}$ & Rank \\
\hline Denmark & 9.3 & 1 & UK & 7.7 & 16 & Angola & 1.9 & 158 \\
\hline Singapore & 9.2 & 4 & USA & 7.3 & 18 & Turkmenistan & 1.8 & 166 \\
\hline Finland & 9 & 5 & France & 6.9 & 23 & Sudan & 1.6 & 173 \\
\hline Canada & 8.7 & 9 & Iran & 2.3 & 141 & Afghanistan & 1.5 & 176 \\
\hline Germany & 7.9 & 14 & Tajikistan & 2 & 151 & Iraq & 1.3 & 178 \\
\hline
\end{tabular}

Generally, corruption in developing countries is more than developed ones (Sanyal \& Guvenli, 2009). Corruption can occur in varied scales, in different forms and in all levels of organizations. An important negative outcome of bureaucratic corruption is its impacts on economic development. Corruption can impact resources allocation, growth process and income distribution in an economy. The evidences of recent studies show that corruption especially bureaucratic corruption impacts negatively on economic development of a community/country (Blackburn et al., 2006). Corruption 
encounters economic growth path with many barriers and impacts on economic development negatively. Such impacts on open economies are more than closed ones (Blackburn \& Puccio, 2010). However, corruption does not always lead into organizational fall. To achieve higher profit, some organizations conduct such initiatives as tax aversion, bribery, corruption, money laundry, etc (Sikka, 2008).

The severity of corruption relates to economic growth, governance system and legal system of any country $(\mathrm{Ng}, 2006)$. According to many authors, one of the main elements of shaping and developing bureaucratic corruption is government. Wideness and size of governments have different potential impacts on bureaucratic corruption. More intervention by government in economic affairs, easier conditions to increase bribery and corruption growth (Goel \& Nelson). The grounds of corruption increase when the government utilizes industrial discriminative policies, price control, multiple foreign currency rates, allocating foreign currency quotas, etc (Miller, 2006).

A way to increase bureaucratic corruption control especially in governmental organizations is free press. More free press, less corruption in various social sectors (Brunetti \& Weder, 2003). Rising distrust and employees' job security can increase the level of corruption in an organization. Hence, policymakers in such organizations should highly respect to employees' promotion and encouragement mechanisms so that employees will be more committed and corruption level will be decreased (Seleim \& Bontis, 2009). Based on a survey by TI, 60\% of studied persons believed that main reason for financial corruption in developing countries was very low salaries of public servants. Most often, in such bureaucratic regimes, the affairs are not moving forward without paying bribery (World Bank, 2007). Additionally, laws and regulations, which cause the length of work processes would increase the grounds of corruption. Such laws create demands for corruption (since people tend to get rid of such rules sooner) and also provide incentives for supply (since employees can prevent performing the works and can cause tendency to bribery by referring to such rules) (Olken, 2008).

\subsection{Types of Bureaucratic Corruption}

As said before, bureaucratic corruption refers to a situation in bureaucratic system in which corruption is occurred due to the impacts of repetitive offences of employees and finally prevents the organization from its expected efficiency and effectiveness. Such offences that are collectively called bureaucratic corruption have different types. The commonest types include:

1. Financial corruption which divides into subcategories like giving and taking bribery, unofficial payments, embezzlement, corruption in purchases by public sector from private sector, corruption in contracts between government and contractors, tax corruption, etc)

2. Personal usage of public assets

3. Less working, false mission reports, spending the time to do works except than main task

4. Burgling public assets by employees

5. Prodigality and dissipation

6. Collusion

7. Preferring relations to norms

8. Corruption in identifying and curbing law infringement

9. Corruption in providing governmental goods and services

10. Corruption in issuing permissions for economic and social activities

11. Corruption in employment (disrespecting meritocracy measures in selecting and promoting people in organization) (Abbas Zadegan, 2004; Vian, 2008).

Bureaucratic corruption does not simply lead into negative outcomes and in unfavorable economic and social conditions, corruption and its outcomes can be fruitful both individually and socially. However, most authors have considered negative outcomes and they believe that corruption is destructive for growth and development (Abbas Zadegan, 2004). For example, corruption rising in a country especially a developed one would increase its foreign direct investment since organizations 
recourse to foreign markets when they observe domestic undesired and corruptive situation (Eggre \& Winner, 2005).

In different conditions and communities, corruption can lead into various and contrast outcomes namely it may be useful for an environment and harmful for another one. For example, authors believe that corruption in Russia has led into economic depression while it has led into economic blossom in China (Larson, 2006). However, it is axiomatic that corruption negative impacts are more than its positive ones.

\subsection{The role of organizational culture in preventing bureaucratic corruption}

Bureaucratic corruption is recognized as a phenomenon and the most important factor against the progress of today community particularly developing countries. Bureaucratic corruption has a complicated nature and eliminating or mitigating this ominous phenomenon in bureaucratic system of countries (Mehri, 2005). In fact, bureaucratic corruption is an organizational phenomenon, which encounters the trend of economic development with serious problems and it is now considered as a qualm for many countries (Alatas et al., 2009). Despite all planning and attention by countries to campaign against this phenomenon, we are still observing its growth trend in various aspects of the society. In terms of fighting against corruption, organizational connoisseurs believe in those approaches that focus is more on prevention rather than curbing such a broad phenomenon through punishment of offended employees (Mahmoodi, 2007).

An important factor, which leads into high corruption in some countries and low corruption in other ones is culture (Alatas et al., 2009). Strong culture, which expresses the commitment of most community members broadly and align individual needs to organizational demands can be a preventive element in curbing corruption. Noteworthy, respecting the issue of culture and powerful cultural constituents is considered as an affecting factor in prevention and using monitoring tools in decisive campaign against offenders is confirmed and is fundamentally evaluated as unavoidable (Taghavi, 2005).

In addition to the fact that employees' dominated culture plays a vital role in decreasing corruption in an organization, unofficial communications between clients and customers of such organization alongside the official role of its employees can remarkably impact on mitigating bureaucratic corruption. Such customers' unofficial communications can create norms, which shape a powerful culture in community against corruption (Kingston, 2008). For example, bribery is considered as an important element of corruption in any organization. On this basis, if community members unofficially promote the culture of non paying bribe, it will also considered as a devil act in organizations and the intensity of bribery will be reduced.

Considering cultural difference to predict corruptive actions is too important for international and multinational companies and it helps such companies to devise proper HR strategies in order to select, to compensate the services, to appraise the performance, and to train/grow their employees (Seleim \& Bontis, 2009).

Regarding the role of culture in preventing bureaucratic corruption, two processes of socialization and ethics are highly important. Based on socialization process, new employed individuals who enter a new workplace should be gotten familiar with the norms of units or teams. These norms tell the members that they should and should not do certain tasks under any spatial situation. If socialization and familiarity processes are done successfully, it will be effective in organizational stability since such a person accepts main and important organizational norms and adopts his/her behavior to them (Zahedi et al., 2009). Ethics and moral requirements pave the ground for long-term growth, development and values rising and lead into minimization of corruption in long term. Noteworthy, ethical norms are impacted by culture, technology and religion and there is no ethical standard level 
for social life in different parts of the world. However, some authors consider the minimum ethical standards for human community (Zekos, 2004). Ethics related to work life closely (Zahedi, 2008). Ethical behavior in workplace is an acceptable behavior in the view of community, organization, individual and a profession. Such behavior highly mitigates the severity of bureaucratic corruption.

Based on a systemic attitude on organization and a phenomenon like bureaucratic corruption shaped by working processes of the organization, one can conclude that a program on bureaucratic corruption prevention should enjoy a systemic style so that all factors that create this phenomenon should be regarded and a preventive system should be devised based on the most important ones. Preventive system means that focused system on corruption and punishment of offenders should be equipped to corruption deteriorating system so that by relying upon a systematic approach, one can resolve the reasons of corruption fundamentally. An important component of such system is organizational culture. The role of organizational culture as a subsystem of structured bureaucratic corruption prevention regime is shown in Fig. 1.

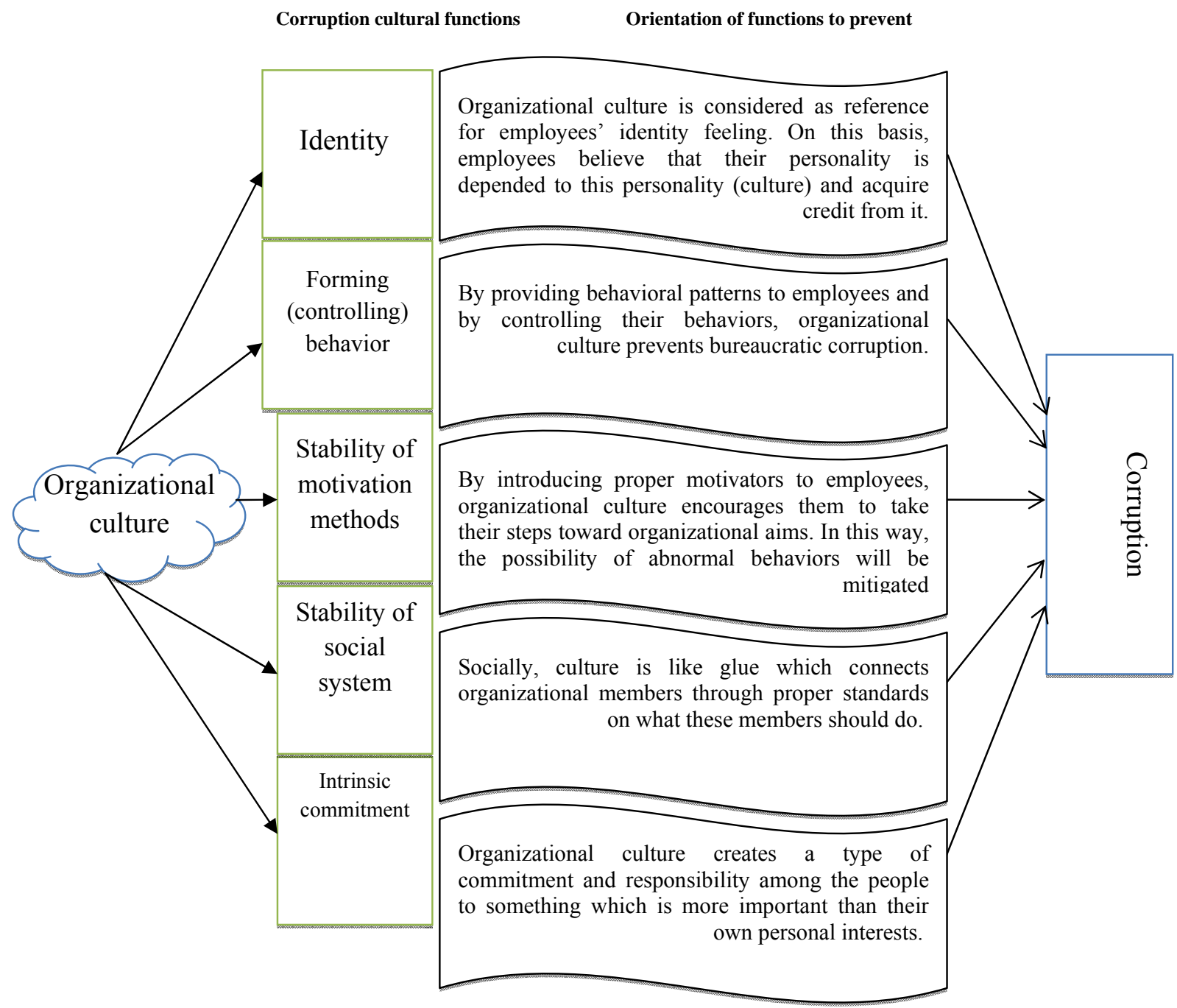

Fig. 1. The Role of Organizational Culture in Preventing Bureaucratic Corruption

As seen, organizational culture through its fundamental functions can impact on employees and have a high capability to prevent bureaucratic corruption. The impact of organizational culture on employees is so high that it is known as the source of shaping unofficial organizations. Organizational culture can be a reference for employees' feeling to identity so that they consider their 
personality depended to organizational culture and acquire credit from it. If the organization enjoys an ideal organizational culture, it can create this mindset among employees that they are valuable people so the possibility of employees' undesired behaviors will be decreased. Another function of organizational culture is that it can conduct employees' behaviors toward certain direction - proper to the content of organizational culture. By providing employees with behavioral patterns, organizational culture guides their behavior and through stabilizing motivational methods and introducing positive motivators to employees, encourages them to take their steps toward organizational goals. In this way, employees would show less interest to abnormal behaviors (Mahmoodi, 2005).

Organizational culture commits employees to themselves and the group. As mentioned, organizational culture closes employees spiritually and mentally and shapes an unofficial organization. On this basis, unofficial organization creates a type of commitment and responsibility to something which is more important their personal interest. Finally, organizational culture is a factor to stabilize social system. Socially, organizational culture is like glue, which connects organizational components through providing proper standards.

\section{Research Methodology}

\subsection{Methodology}

In terms of problem and aim, this is an applied study and in terms of methodology, it is a descriptive - correlative one. To gather needed data, two questionnaires with Likert five-scale responses were used. Initially, by distributing the first questionnaire, four organizations namely two bureaucratic and two organic organizations were selected. The second questionnaire was distributed among employees and clients of organizations (to acquire more realistic information on the extent of bureaucratic health) in order to study the relationship between the type of organizational culture and the extent of bureaucratic health. In fact, the first questionnaire tested organizational culture variable and the second one tested the relationship between organizational culture and bureaucratic variables.

\subsection{Reliability}

In present study, Chronbach's alpha coefficient is used to study and confirm questionnaire's reliability. The amounts of Chronbach's alpha for both questionnaires are depicted in table 3. As seen, Cronbach's alpha ratios for both questionnaires are acceptable.

Table 3

Chronbach's Alpha Ratios for $1^{\text {st }}$ and $2^{\text {nd }}$ Questionnaires

\begin{tabular}{ccc}
\hline Questionnaire & Alpha & Status \\
\hline A & $91.7 \%$ & Acceptable \\
B & $93.7 \%$ & Acceptable \\
\hline
\end{tabular}

\subsection{Statistical population and sample}

The research consists of two statistical populations:

(A) Employees' population which includes all public servants in Chabahar. However, two groups were selected since all employees were not available.

1. Organizations with bureaucratic organizational culture whose power is less distributed and the power is concentrated at the top of the organization. Governorship and Traffic Police were 
selected for this group. Noteworthy, the reason for such selection was the existence of proper grounds to cooperate with the author.

2. Organizations with organic organizational culture whose power is more distributed and the power is in low levels. Such organizations are less concentrated. Customs and Municipality were selected for this group. Noteworthy, the reason for such selection was the existence of proper grounds to cooperate with the author.

(B) Clients' population which is indefinite and consists of all organizational clients.

To study organizational culture and the level of bureaucratic health, four organizations (Municipality, Governorship, Customs and Traffic Police) are considered. Since recognition of sample group was too important in present study to extend its aims, we used regular random sampling method. To evaluate organizational culture variable, the sample consisted of 146 (114 males and 32 females) and to measure bureaucratic health variable a combination of 146 employees and clients (137 clients including 57 males and 16 females and 73 male employees) was considered. Sampling framework for employees by organization is outlined in table 4. It should be noted that Morgan's table is the basis of selected the studied sample.

Table 4

Sampling Framework for Employees

\begin{tabular}{cccc}
\hline Organization & $\begin{array}{c}\text { Number of employees } \\
\text { in organization }\end{array}$ & $\begin{array}{c}\text { The ratio of employees in each } \\
\text { organization to total population }\end{array}$ & $\begin{array}{c}\text { The quantity of selected sample of } \\
\text { employees in each organization (sample of } \\
\text { employees }\end{array}$ \\
\hline Municipality & 40 & $23 \%$ & 34 \\
Governorship & 30 & $18 \%$ & 28 \\
Customs & 80 & $47 \%$ & 66 \\
Traffic Police & 20 & $12 \%$ & 18 \\
\hline Total & 170 & $100 \%$ & 146 \\
\hline
\end{tabular}

\subsection{Research Hypotheses}

Regarding the theoretical literature and background, five hypotheses are considered in present study as follow (the fifth hypothesis is the main hypothesis of the research):

1. Organizational culture of Customs is organic.

2. Organizational culture of Municipality is organic.

3. Organizational culture of Governorship is bureaucratic.

4. Organizational culture of Traffic Police is bureaucratic.

5. There is a significant relationship between organizational culture and bureaucratic system health in organizations.

To understand the way of studying the hypotheses better, graph 3 shows the data analysis process to reject or to support the hypotheses step-by-step.

\section{Testing the hypotheses and research findings}

In present study, we examine hypotheses $1-4$ by using average and t student tests in order to see whether they are true in organizations or not. In the next stage, we use correlation test to test hypothesis 5 by all four organizations.

\subsection{Hypotheses 1 - 4}

Computed statistics and the results of average test and t test to assess organizational culture in all four studied organizations are shown in table 5. Outlined data in this table is extracted from the $1^{\text {st }}$ questionnaire on organizational culture. In statistical analysis of results in table 5, if the average in an organization is greater or equal to $3(\mu \geq 3)$, its organizational culture is organic and if this figure is 
less than 3, its organizational culture is bureaucratic. Since the significance level for all four studied organizations is less than 0.05 , so one can accept the results with $95 \%$ as confidence level. The averages for Customs and Municipality are greater than 3. Therefore, one can conclude that their organizational culture is more organic. Hence, hypotheses 1 and 2 are supported. The averages for Governorship and Traffic Police are less than 3. Therefore, one can conclude that their organizational culture is more bureaucratic. Hence, hypotheses 3 and 4 are supported.

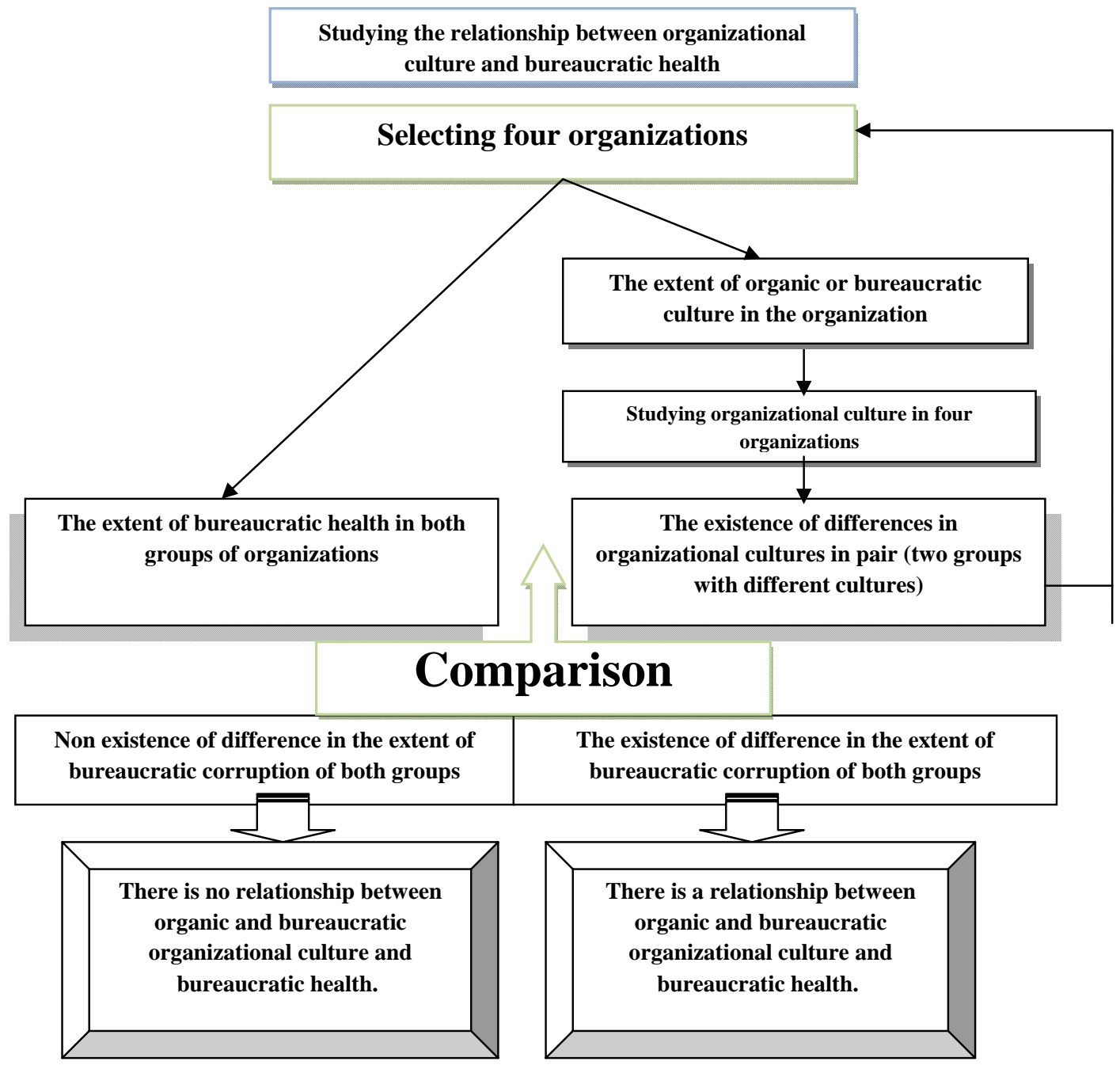

Fig. 3. Data Analysis Process to Support or Reject Hypotheses

\subsection{Testing hypothesis 5}

It studies the relationship between organizational culture and the extent of bureaucratic health in organization. To examine such relationship between organizational culture and employees' bureaucratic health, Pearson's correlation coefficient is used. Correlation coefficient between organizational culture and bureaucratic health in all four studied organizations is depicted in table 6 . As seen, the level of significance error (sig) is greater than test level (0.05) in all four organizations. Therefore, one can conclude that there is no significant relationship between organizational culture and bureaucratic health in all four studied organizations and acquired correlation coefficient in table 6 has been the result of sampling error and chance. Therefore, hypothesis 5 is rejected. 


\section{Table 5}

The Results of Average and T Tests for Data on Organizational Culture (Test Value =3)

\begin{tabular}{|c|c|c|c|c|c|c|c|c|c|}
\hline \multirow[b]{2}{*}{ Organization } & \multirow[b]{2}{*}{ Qty } & \multirow[b]{2}{*}{ Average } & \multirow{2}{*}{$\begin{array}{l}\text { Standard } \\
\text { deviation }\end{array}$} & \multirow[b]{2}{*}{$\mathrm{T}$} & \multirow{2}{*}{$\begin{array}{c}\text { Freedom } \\
\text { degree }\end{array}$} & \multirow[b]{2}{*}{) $\operatorname{sig}($} & \multirow{2}{*}{$\begin{array}{l}\text { Difference } \\
\text { to average }\end{array}$} & \multicolumn{2}{|c|}{$95 \%$ confidence distance } \\
\hline & & & & & & & & Lower level & Higher level \\
\hline Customs & 66 & 3.4459 & .42268 & 8.570 & 65 & .000 & .44589 & .3420 & .5498 \\
\hline Municipality & 34 & 3.9664 & 69902 & -.280 & 33 & .007 & -.03361 & -.2775 & .2103 \\
\hline Governorship & 28 & 2.4337 & .48325 & -6.201 & 27 & .000 & -.56633 & -.7537 & -.3789 \\
\hline Traffic Police & 18 & 1.6349 & .33313 & -17.385 & 17 & .000 & -1.36508 & -1.5307 & -1.1994 \\
\hline
\end{tabular}

Table 6

Pearson's Correlation Coefficient between Organizational Culture and Bureaucratic Health in All Four Studied Organizations (Test Value = 3)

\begin{tabular}{cccc}
\hline Organization & Sample quantity & ) $\operatorname{sig}($ & Pearson's correlation coefficient \\
\hline Customs & 66 & .375 & .111 \\
Municipality & 34 & .486 & -.124 \\
Governorship & 28 & .628 & .096 \\
Traffic Police & 18 & .130 & -.371 \\
\hline
\end{tabular}

One can examine hypothesis 5 by the average of health score in studied organizations. Table 7 indicates the average of health score in four studied organizations. Noteworthy, as seen in Table 7, greater average of bureaucratic health score of an organization means lower bureaucratic health. In other words, the extent of corruption and financial/bureaucratic offences are higher. As observed in Table 7, Traffic Police has the highest bureaucratic health score followed by customs, Municipality and Governorship. Therefore, one can conclude that Traffic Police with the highest bureaucratic health score has the lowest level of bureaucratic health among four studied organizations and the levels of bureaucratic health score are higher in Customs, Municipality and Governorship respectively (Governorship has the highest level of bureaucratic health followed by Municipality, Customs and Traffic Police).

Table 7

The Averages of Bureaucratic Health Scores in Studied Organizations

\begin{tabular}{|c|c|c|c|c|c|c|c|c|}
\hline \multirow{2}{*}{ Bureaucratic health } & \multirow[b]{2}{*}{ Qty } & \multirow{2}{*}{$\begin{array}{c}\text { Average } \\
\text { score }\end{array}$} & \multirow{2}{*}{$\begin{array}{l}\text { Standard } \\
\text { deviation }\end{array}$} & \multirow{2}{*}{$\begin{array}{c}\text { Standard } \\
\text { error }\end{array}$} & \multicolumn{2}{|c|}{$95 \%$ confidence distance } & \multirow[b]{2}{*}{ Minimum } & \multirow[b]{2}{*}{ Maximum } \\
\hline & & & & & Lower level & Higher level & & \\
\hline Governorship & 28 & 39.5714 & 14.23722 & 2.69058 & 34.0508 & 45.0920 & 19.00 & 61.00 \\
\hline Municipality & 34 & 39.8824 & 12.36752 & 2.12101 & 35.5671 & 44.1976 & 21.00 & 66.00 \\
\hline Traffic Police & 18 & 43.5000 & 12.51470 & 2.94974 & 37.2766 & 49.7234 & 19.00 & 62.00 \\
\hline Customs & 66 & 42.7121 & 15.57094 & 1.91665 & 38.8843 & 46.5399 & 19.00 & 69.00 \\
\hline Total & 146 & 41.5479 & 14.21611 & 1.17653 & 39.2226 & 43.8733 & 19.00 & 69.00 \\
\hline
\end{tabular}

\section{Conclusion}

Bureaucratic corruption is a phenomenon that in today world especially in developing countries is considered as an important barrier against social progress. This phenomenon has been able to pose irrevocable damages on the development pace of a society. Bureaucratic corruption is like a virus, which can lead into government overturn and public/private institutes distrust. It has a destructive impact on bureaucratic system. Bureaucratic corruption weakens the society and promotes the pressure especially on low-income groups. Hence, bureaucratic corruption should be prevented and curbed in all its forms. To achieve such aims, it is necessary to predict proper guidelines in order to assure employees' health by governments, to grow transparency in financial operations by relevant entities and to implement powerful criteria in terms of responsibility by private sector. Although efforts to prevent corruption are getting complicated day by day, in fighting against bureaucratic 
corruption, it is highly important to provide proper executive guidelines in preventing bureaucratic corruption except than direct campaign against corruption cases based on laws and regulations.

The results of statistical analyses show that research hypotheses 1 to 4 are supported. It means that among four studied organizations, Customs and Municipality have organic culture and Governorship and Traffic Police have bureaucratic culture. In contrary to expectations, the $5^{\text {th }}$ hypothesis as the research main hypothesis on the existence of a relationship between organizational culture and bureaucratic corruption in organizations was rejected. Therefore, one can say that organizational culture in Customs and Municipality is organic and organizational culture in Governorship and Traffic Police is bureaucratic. However, there is no significant relationship between organic/bureaucratic organizational culture and bureaucratic system health in Chabahar's public organizations. Research findings indicate that organic/bureaucratic organizational culture cannot be considered as an important factor in the health of bureaucratic system. However, one cannot neglect the impact of organizational culture on bureaucratic system health. In fact, organizational culture can be a preventing factor in emerging bureaucratic corruption. Therefore, one can say that the health of bureaucratic system can be partly increased by working on organizational culture.

Regarding organizational complicated problems, it may not be possible to find a certain factor as the only affecting factor on organizational affairs. So, organizational culture issue may be considered as a key factor in a certain region or organization and as an unimportant factor in another region or organization. However, organizational culture is considered as a controlling factor which causes the creation or shaping the attitudes in employees' behaviors so that individual's competency, attitudes and behavior with regard to organizational culture can lead such individual into a member of the organization. Organizational culture is a tool which facilitates our treatment to organizational problems and forms our interpretation of surrounding events. Hence, one can say that culture is a key tool to curb corruption in organizations.

Therefore, simply organic/bureaucratic organizational culture in studied organizations has no role in mitigating bureaucratic corruption. One cannot neglect the impacts of culture on bureaucratic corruption. Organizations should build a proper culture in fighting against culture. Building such culture needs long term planning and one cannot build a proper culture and hope to avoid corruption by a few short term initiatives.

\section{References}

Alatas, V. Cameron, L. Chaudhuri, A. Erkal., N. \& Gangadharan, L. (2009). Gender, Culture, and Corruption: Insights from an Experimental Analysis. Southern Economic Journal., 75(3), 663-680.

Barney, J.B. \& Griffin, R.W. (1999). The Management of Organization: Strategy, Structure, Behavior. Houghton Mifflin Co. Boston, p5.

Barzegar, J. (2003). The reasons of rising bureaucratic/financial corruption and the ways to prevent and curb against it in Iran, Tadbir, vol. 330.

Berthon, P. Pitt, L. Berthon, J.P. Campbell, C. \& Thwaites, D. (2008). E-Relationships for e-Readiness: Culture and corruption in international e-B2B. Industrial Marketing Management, 37, 83-91.

Blackburn, K. Bose, N. \& Hague, M.E. (2006). The incidence and persistence of corruption in economic development. Journal of Economic Dynamics \& Control, 30, 2447-2467.

Blackburn, K., Gonzalo, F., \& Forgues, P. (2010). Financial liberalization, bureaucratic corruption and economic development. Journal of International Money and Finance, 29, 1321-1339.

Brunetti, A. \& Weder, B. (2003). A free press is bad news for corruption. Journal of Public Economics, $87,1801-1824$.

Scott, C.(1972). Comparative Political Corruption. Prentice Hall.

Cheung, S. O., Wong, P. S.P., \& Wu, A. W.Y. (2011). Towards an organizational culture framework in construction. International Journal of Project Management, 29, 33-44.

Ashforth, E. B. \& Anand, V. (2003). The normalization of corruption in organization. Research in Organizational Behavior, 25, 1-52 
Egger, P. \& Winner, H. (2005). Evidence on corruption as an incentive for foreign direct investment. European Journal of Political Economy, 21, 932-952.

Habiby, N. (1996). Bureaucratic Corruption. Vosgha Publications

Huczynski, A. \& Buchanan, D.A. (1995). Organization: A Critical Introduction. Macmillan Co, p3

Jafary, M. \& Habiby, M. (2002). Work culture and guidelines to promote it. Tadbir, 125 .

Johnson, G. \& Scholes, K. (1993). Exploring Corporate Strategy. $33^{\text {rd }}$ edition .Prentice - Hall, Hempstead, p82

Goel, R. K., \& Nelson, M. A. (2010). Causes of corruption: History, geography and government. Journal of Policy Modeling, 32, 433-447.

Kingston, K. (2008). Social structure and cultures of corruption. Journal of Economic Behavior \& Organization, 67, 90-102

Ksenia (2008). Can corruption and economic crime be controlled in developing countries and if so, is it cost-effective? Journal of Financial Crime, 15(2), 223-233.

Larmour, P. (2001). Corruption, culture and transferability: What can be learned from Australia? Journal of Contingencies and Crisis Management. 9(1), 14-20.

Larsson, T. (2006). Reform, corruption, and growth: Why corruption is more devastating in Russia than in China. Communist and Post-Communist Studies, 39, 265-281.

Lau, C.M. \& Ngo, H.Y. (1996). One country many cultures: Organizational cultures of firms of different country origins. International Business Review, 5(5), 469-486.

Mahmoodi, M. (2005). The role of organizational culture in preventing bureaucratic corruption, Tadbir, 154 (In Farsi).

Mehry, G.A. (2005). The role of organizational culture in preventing bureaucratic corruption. Tadbir, 160 (In Farsi).

Miller, W. L. (2006). Corruption and Corruptibility. World Development, 2.

Mungiu-Pippidi, A. \& A. Dusu, A.E. (2011). Civil society and control of corruption: Assessing governance of Romanian public universities. International Journal of Educational Development, 31, $532-546$

Nedaei, M. (1999), organizational culture typology. Mesbah Quarterly, 31.

$\mathrm{Ng}$, D. (2006). The impact of corruption on financial markets. Managerial Finance, 32(10), 822-836.

Olken, B. (2007). Monitoring corruption: Evidence from a field experimenting Indonesia. Journal of Political Economy, 115(2).

Palmer, D. (2008). Extending the process model of collective corruption. Research in Organizational Behavior, 28, 107-135

Ranaei, K. (2006). Competitive values in organizational culture researches. Management Culture Journal., 15.

Robins, S. (2007). Organizational Behavior Foundations., Cultural Research Publications, vol. 16

Sanyal., R. \& Guvenli, T. (2009). The propensity to bribe in international business: the relevance of cultural variables. Cross Cultural Management, 16(3), 287-300.

Seleim, A. \& Bontis, N. (2009). The relationship between culture and corruption: a cross-national study. Journal of Intellectual Capital., 10(1), 165-184.

Sikka, P. (2008). Enterprise culture and accountancy firms: new masters of the universe. Accounting, Auditing \& Accountability Journal., 21(2), 268-295.

Transparency International (TI), (2008). Economic Development Institute of the word bank \& Jeremy, Building Integrity to Fight

Vian, T. (2008). Corruption and the Consequences for Public Health. Boston University School of Public Health, pp 26-33

World Bank (2004). Helping countries combat corruption: the role of the World Bank. Poverty reduction and economic management.

World Bank (2007). Worldwide Governance Indicators 2007: Country Data Report for Iran, 1996- 2006.

Zahed, S. (2006). A view on corruption and its ramifications. Management Knowledge Journal., 2.

Zahedi, S., Mohammad Nabi, S. \& Shahbazi, M. (2009), studying affecting factors on mitigating bureaucratic corruption (case study in Tehran). Organizational Culture Management Journal., 20.

Zekos, G. (2004). Ethics versus Corruption in Globalization. Journal of Management Development, 23(7), 631-647. 